\title{
Dokter Mogok Kerja: Sebuah Tinjauan Etika
}

\author{
Azharul Yusri ${ }^{1}$ Putri Dianita Ika Meilia ${ }^{2,3}$ \\ ${ }^{\mathrm{I}}$ Majelis Kehormatan Etik Kedokteran Wilayah Riau \\ ${ }^{2}$ Majelis Kehormatan Etik Kedokteran Pengurus Besar Ikatan Dokter Indonesia \\ ${ }^{3}$ Instalasi Kedokteran Forensik dan Pemulasaraan Jenazah, Rumah Sakit Umum Pusat Persahabatan, Jakarta
}

\author{
Kata Kunci \\ demo, dokter, etika, mogok kerja \\ Korespondensi \\ contact@ilmiah.id \\ Publikasi \\ (C) 2019 JEKI/ilmiah.id \\ DOI \\ I0.26880/jeki.v3ii.30 \\ Tanggal masuk: 31 Oktober 2018 \\ Tanggal ditelaah: 13 Januari 2019 \\ Tanggal diterima: 20 Januari 2019 \\ Tanggal publikasi: 26 Februari 2019
}

\begin{abstract}
Abstrak Mogok kerja adalah tindakan pekerja secara bersamasama menghentikan atau memperlambat pekerjaan sebagai akibat gagalnya perundingan atas tuntutan atau pelaksanaan hak normatif. Namun, profesi dokter dan tenaga kesehatan lainnya merupakan profesi yang luhur, yang memiliki kewajiban moralyang lebih "tinggi". Paradigma populer di masyarakat adalah "Dokter tidak boleh mogok melayani pasien karena menyangkut jiwa manusia". Aksi dokter mogok sesungguhnya melanggar berbagai prinsip dan hukum, termasuk kode etik dan sumpah Dokter. Kepentingan pasien (dan masyarakat) semestinya didahulukan dibandingkan kepentingan pribadi atau golongan. Selaku kaum intelektual, dokter seharusnya merasa memiliki bargaining power yang cukup sehingga tidak perlu mengambil jalan mogok kerja untuk menyampaikan aspirasinya. Jika, dan hanya jika, semua strategi musyawarah telah dilaksanakan dan gagal, maka mogok kerja mungkin dapat dipertimbangkan dengan ketentuan semua kasus gawat darurat tetap harus ditangani, mogok kerja bertujuan untuk memperjuangkan kepentingan pasien (bukan kepentingan pribadi atau golongan) sebagai tujuan akhirnya, dan semua dokter yang berpartisipasi yakin secara moral bahwa memang tidak ada jalan lain untuk memperjuangkan kepentingan pasien tersebut.
\end{abstract}

Abstract Job strike is an action where workers jointly stopping or slowing down works as a result of failed negotiations over demands or implementation of normative rights. However, the profession of doctors and health workers are noble professions, with "higher" moral obligations. The popular paradigm in the community is "Doctors should not strike to serve patients because it involves human life". When doctors go on a strike, it actually violates various principles and laws, including the code of ethics and the Doctor's Pledge. The interests of patients (and society) should take precedence over personal or group interests. As intellectuals, doctors should acknowledge that they have sufficient bargaining power so they do not need a strike to convey their aspirations. If, and only if, all mediatory strategies have been implemented and failed, then a strike may be considered provided that all emergency cases must be taken care of, the strike aims to fight for patients' interests (not personal or group interests) as ultimate goal, and all doctors who participate are morally convinced that there is no other way to fight for the patients' interests.

\begin{tabular}{ll} 
Mogok kerja adalah tindakan pekerja & sebagai wujud dari hak atas kebebasan berserikat \\
secara bersama-sama menghentikan atau & dan perlindungan atas hak berorganisasi. Pada \\
memperlambatpekerjaan sebagaiakibatgagalnya & tataran global, mogok sebagai hak tercantum \\
perundingan atas tuntutan atau pelaksanaan & pada pasal 23 ayat (4) Universal Declaration \\
hak normatif. Mogok kerja diakui sebagai salah & of Human Rights yang menjamin hak setiap \\
satu hak dasar pekerja/ buruh secara universal, & orang untuk membentuk dan menjadi anggota \\
\hline
\end{tabular}


serikat buruh guna melindungi kepentigannya. Pengaturan mengenai mogok kerja diatur khusus pada Pasal 137 sampai Pasal 145 dalam Undang-Undang No. 13 Tahun 2003 tentang Ketenagakerjaan. Peraturan pelaksanaan mogok kerja diatur oleh Kepmenakertrans No. 232/ MEN/2003 tentang Akibat Hukum Mogok Kerja Yang Tidak Sah. ${ }^{1}$

Paradigma populer di masyarakat adalah "Dokter tidak boleh mogok melayani pasien karena menyangkut jiwa manusia”. Profesi kedokteran merupakan profesi yang tertua dan dikenal sebagai profesi yang mulia karena ia berhadapan dengan hal yang paling berharga dalam hidup seseorang yaitu masalah kesehatan, kehidupan dan kematian. ${ }^{2}$ Hal ini berbeda dampaknya bila buruh yang mogok, maka hanya berdampak matinya mesin produksi. ${ }^{1,3}$

Menurut Pasal 1 butir 11 Undang Undang Nomor 29 Tahun 2004 tentang Praktik Kedokteran, profesi kedokteran atau kedokteran gigi adalah suatu pekerjaan kedokteran atau kedokteran gigi yang dilaksanakan berdasarkan suatu keilmuan, kompetensi yang diperoleh melalui pendidikan berjenjang dan kode etik yang bersifat melayani masyarakat. Dengan kata lain profesi bukanlah pekerjaan biasa. Pekerjaan profesi (professio berarti pengakuan) merupakan pekerjaan yang memerlukan pendidikan sesuai standar, mengutamakan panggilan kemanusiaan, berlandaskan etik profesi yang mengikat seumur hidup, legal memerlukan perizinan, belajar sepanjang hayat, dan anggotanya bergabung dalam satu organisasi profesi. ${ }^{2,4,5}$

Baru-baru ini kita dihebohkan oleh surat dari Perhimpunan Dokter Spesialis Bedah Indonesia (IKABI) Korwil Riau yang menghimbau kepada seluruh anggota IKABI Korwil Riau untuk menghentikan pelayanan operasi elektif dan poliklinik hingga waktu yang tidak ditentukan. Mogok ini didasari sebagai aksi solidaritas karena ditahannya tiga orang dokter spesialis bedah oleh Kejaksaan Negeri Pekanbaru. Apakah dokter yang melakukan mogok menghentikan pelayanan pasien dapat dikategorikan telah melakukan pelanggaran etika kedokteran? Tulisan ini bertujuan menelaah aspek etika dan hukum tindakan mogok oleh dokter.

\section{Hak Pasien}

Rumusan hak pasien tidaklah sekali jadi, tetapi melalui tahap-tahap perkembangannya. Dalam UUD RI 1945 Amandemen 2 pasal 28H ayat (1) disebutkan: Setiap orang berhak hidup sejahtera lahir dan batin, bertempat tinggal, dan mendapatkan lingkungan hidup yang baik dan sehat serta berhak memperoleh pelayanan kesehatan. Dalam UU RI No. 29 Tahun 2004 tentang Praktik Kedokteran Hak Pasien dicantumkan dalam pasal 52. Pasien dalam menerima pelayanan pada praktik kedokteran mempunyai hak: (a) mendapatkan penjelasan secara lengkap tentang tindakan medis sebagaimana dimaksud dalam pasal 45 ayat 3 . (b) meminta pendapat dokter atau dokter gigi lain. (c) mendapatkan pelayanan sesuai dengan kebutuhan medis. (d) menolak tindakan medis. (e) mendapatkan isi rekam medis. Hal ini jelas menunjukkan bahwa aksi dokter mogok adalah pelanggaran HAM dan melanggar hukum.,

Dalam Peraturan Konsil Kedokteran Indonesia No. 4 Tahun 2011 tentang Disiplin Profesional Dokter dan Dokter Gigi pasal 3 ayat (2) huruf (p) disebutkan: Pelanggaran Disiplin Profesional Dokter dan Dokter Gigi sebagaimana dimaksud pada ayat (1) terdiri dari 28 bentuk: ... (p) menolak atau menghentikan tindakan/asuhan medis atau tindakan pengobatan terhadap pasien tanpa alasan yang layak dan sah sesuai dengan ketentuan etika profesi atau peraturan perundang-undangan yang berlaku. Pasal ini menyiratkan bahwa segala bentuk penolakan dan penghentian pelayanan kedokteran tanpa alasan yang layak dan sah adalah bentuk pelanggaran disiplin professional dokter. ${ }^{?}$

\section{Kewajiban Dokter}

Dalam menjalankan tugasnya bagi dokter berlaku "Aegroti Salus Lex Suprema" yang berarti keselamatan pasien adalah hukum yang tertinggi (yang utama). ${ }^{2}$ Dalam Undang Undang No. 29 Tahun 2004 tentang Praktik Kedokteran Pasal 51 dinyatakan bahwa kewajiban dokter atau dokter gigi antara lain adalah memberikan pelayanan medis sesuai dengan standar profesi dan 
standar prosedur operasional serta kebutuhan medis pasien, melakukan pertolongan darurat atas dasar perikemanusiaan, kecuali jika ia yakin ada orang lain yang bertugas dan mampu melakukannya, serta menambah ilmu pengetahuan dan mengikuti perkembangan ilmu kedokteran atau kedokteran gigi. ${ }^{5}$

\section{Tinjauan Etik}

Dokter terikat oleh lafal sumpah dokter, di mana penulis mencermati dalam kaitan mogok kerja dokter ini ada beberapa poin sumpah dokter yang dilanggar: ${ }^{4,8}$

1. Bahwa dokter akan membaktikan hidupnya guna kepentingan perikemanusian, Artinya bahwa tindakan dokter haruslah untuk kepentingan perikemanusian;

2. Bahwa dokter akan menjalankan tugas dengan cara terhormat dan bersusila, artinya seorang dokter yang meninggalkan tugasnya menjadi seseorang dokter yang hilang atau berkurang sifat terhormat dan bersusilanya;

3. Bahwa dokter itu wajib memelihara dengan sekuat tenaga martabat dan tradisi luhur profesi kedokteran, artinya bahwa apapun perilaku dokter haruslah menjaga martabat bahwa profesi dokter ini adalah profesi yang luhur; dan

4. Bahwa dokter senantiasa mengutamakan kesehatan pasien, dengan memperhatikan kepentingan masyarakat, artinya bahwa serangkaian tindakan pelayanan kedokteran harus mengutamakan pasien dan masyarakat secara umum.

Pernyataan ini diperkuat oleh Kewajiban Umum Dokter dan Kewajiban Dokter Terhadap Pasien. Pada pasal 8 pada KODEKI Tahun 2012 tentang profesionalisme, pasal tersebut menyatakan bahwa dalam setiap praktik medisnya seorang dokter wajib memberikan pelayanan secara berkompeten dengan kebebasan teknis dan moral sepenuhnya, disertai rasa kasih sayang (compassion) dan penghormatan atas martabat manusia. Melalui penjelasannya, pasal ini mewajibkan seorang dokter untuk menjalankan praktik profesi yang bertanggung jawab dan bermutu. Ada 3 tanggung jawab profesi yakni: (a) kepada diri sendiri (responsibility) dalam rangka menjalankan kebebasan teknis profesi berdasar kompetensi masing-masing, (b) kepada teman sejawat dan lingkungan kerja (accountability), dan (c) kepada klien/pasien sebagai pihak ketiga (liability). Profesionalisme dihasilkan dari tanggung jawab moral sepenuhnya, adanya kasih sayang dan penghormatan hak asasi manusia karena pasien merupakan wujud insan bermartabat. Pernyataan ini menyiratkan bahwa aksi mogok kerja adalah bentuk penentangan terhadap pasal ini, maka dokter akan berurusan dengan MKEK.2,4,8

Pada pasal 10 pada KODEKI tahun 2012 tentang penghormatan hak-hak pasien dan sejawat, pasal tersebut menyatakan bahwa dalam melakukan pekerjaannya seorang dokter wajib senantiasa menghormati hak-hak pasien, teman sejawatnya, dan tenaga kesehatan lainnya, serta wajib menjaga kepercayaan pasien. Melalui penjelasannya, pasal ini mewajibkan seorang dokter untuk menjalankan praktik profesi yang mengedepankan adanya panggilan nurani menolong pasien sebagai manusia yang tengah menderita sebagai kewajiban tertinggi dokter sebagai pengabdi profesi. Penghormatan hakhak pasien dan teman sejawat yang merupakan bagian dari kewajiban dokter akan menjaga kepercayaan pasien, agar dapat mempercepat kesembuhannya. Pernyataan ini menyiratkan juga bahwa aksi mogok kerja dokter adalah bentuk penentangan terhadap pasal ini, di mana menghormati hak-hak pasien adalah sebagai kewajiban tertinggi seorang dokter. ${ }^{8}$

\section{Situasi Global}

Peristiwa mogok kerja (strike) oleh dokter, dan tenaga kesehatan secara umum, tidak hanya terjadi di Indonesia dan bukan merupakan fenomena baru. Berbagai kondisi kerja, sistem kesehatan, sistem pembiayaan layanan kesehatan, atau pun situasi sosial-politik di berbagai negara pernah menyebabkan kalangan dokter melakukan mogok kerja, misalnya di Inggris, Amerika, Kanada, India, Pakistan, dan lain-lain. ${ }^{9}$ Pandangan para ahli tentang aspek etika dan hukum mogoknya dokter dan tenaga kesehatan pun berbeda-beda. Namun, secara umum pendapat yang dominan adalah sebagai berikut: ${ }^{10-12}$ Profesi dokter, dan tenaga 
kesehatan lainnya, merupakan profesi yang luhur, yang memiliki kewajiban moral yang lebih "tinggi". Kepentingan pasien (dan masyarakat) merupakan kepentingan yang overriding, yaitu yang semestinya didahulukan dibandingkan kepentingan pribadi atau golongan. Sekalipun dirancang agar tidak mengganggu pelayanan (misalnya, hanya menolak kasus elektif/nongawat darurat) tetap ada kepentingan pasien yang dikorbankan. Padahal, profesi dokter memiliki "kontrak kinerja" dengan pasien berupa clinical privilege. Dengan demikian, mogok kerja bukanlah bentuk respons yang dapat dibenarkan terhadap suatu masalah, dan justru dapat mengubah dokter yang seharusnya bersifat beneficent menjadi dokter yang maleficent.

\section{Tindakan Alternatif}

Strategi mogok kerja pada umumnya terpaksa diambil dalam situasi di mana terdapat ketimpangan yang jauh antara sang pemberi kerja (employer) dengan sang pekerja (employee/ labourer). Dalam situasi tersebut, pekerja tidak memiliki bargaining power yang cukup untuk membuat pemberi kerja mendengarkan dan memenuhi permintaannya. Dengan melakukan mogok kerja, pekerja berharap dapat memberikan tekanan kepada pemberi kerja dengan "mengorbankan" kepentingan pihak ketiga, yang diharapkan turut menekan pemberi kerja. Dalam profesi kedokteran, yang terpaksa dikorbankan adalah kepentingan pasien selaku pihak ketiga yang "tak berdosa", dan yang notabene merupakan pemberi clinical privilege, sehingga menimbulkan dilema etik. ${ }^{13}$ Selain itu, dapat timbul kemarahan dan kekecewaan dari pihak pasien, dan masyarakat secara umum, karena merasa dirugikan sehingga justru tidak simpati dengan aspirasi yang hendak disampaikan oleh dokter melalui aksi mogok kerja.

Selaku kaum intelektual, dokter seharusnya merasa memiliki bargaining power yang cukup sehingga tidak perlu mengambil jalan mogok kerja untuk menyampaikan aspirasinya. Jalan yang dapat ditempuh dapat berupa dialog, musyawarah, mediasi, atau arbitrasi, baik secara personal maupun antar lembaga terkait. Jika, dan hanya jika, semua strategi musyawarah telah dilaksanakan dan gagal, maka mogok kerja mungkin dapat dipertimbangkan dengan ketentuan sebagai berikut: ${ }^{11}$

1. Semua kasus gawat darurat tetap harus ditangani,

2. Mogok kerja bertujuan untuk memperjuangkan kepentingan pasien (bukan kepentingan pribadi atau golongan) sebagai tujuan akhirnya, dan

3. Semua dokter yang berpartisipasi dalam mogok kerja yakin secara moral bahwa memang tidak ada jalan lain untuk memperjuangkan kepentingan pasien tersebut.

Dengan kemampuan leadership dan manajerial yang dimilikinya, dokter semestinya mencari alternatif strategi yang lebih kreatif, etis, dan elok. untuk mencapai win-win solution untuk semua pihak.

\section{KESIMPULAN}

Munculnya fenomena dokter melakukan mogok kerja dengan berbagai alasan perlu disikapi karena kasusnya menunjukkan tren peningkatan dan berpotensi mencederai martabat dan tradisi luhur profesi kedokteran. Dokter seyogyanya kembali mengingat sumpah dokter dan berpedoman kepada Kode Etik Kedokteran Indonesia (KODEKI). Aksi mogok kerja yang dilakukan oleh dokter sendiri-sendiri atau bersama-sama adalah bentuk pelanggaran Etika Kedokteran. Tidak ada pemenang dari aksi mogok kerja, yang ada hanya kemarahan, rasa tidak simpati, dan pengorbanan kepentingan. Majelis Kehomatan Etika Kedokteran (MKEK) perlu menerbitkan fatwa/pernyataan sikap terkait aksi dokter mogok kerja ini untuk menjaga martabat dan tradisi luhur profesi kedokteran.

\section{KONFLIK KEPENTINGAN}

Tidak ada konflik kepentingan. 


\section{REFERENSI}

1. Keputusan Menteri Tenaga Kerja dan Transmigrasi Nomor 232/MEN/2003 tentang Akibat Hukum Mogok Kerja yang Tidak Sah. 2003.

2. Hanafiah MJ. Etika Kedokteran dan Hukum Kesehatan. 5th ed. Jakarta: EGC; 2016.

3. Farianto W. Hak Mogok Kerja dalam Perspektif Yuridis dan Sosiologis. J Huk Ius Quia Iustum. 2014;21(4):632-54.

4. Dewi AI. Etika dan Hukum Kesehatan. Yogyakarta: Pustaka Book Publisher; 2008.

5. Undang-Undang Republik Indonesia Nomor 29 Tahun 2004 tentang Praktik Kedokteran. 2004.

6. Undang-Undang Dasar Negara Republik Indonesia Tahun 1945 Amandemen IV. 2002.

7. Peraturan Konsil Kedokteran Indonesia Nomor 4 Tahun 2011 tentang Disiplin Profesional Dokter dan Dokter Gigi. 2011.

8. Pengurus Besar Ikatan Dokter Indonesia. Kode etik kedokteran Indonesia. Jakarta; 2012.

9. Davies M. Is it ethical for doctors to strike? BMJ. 2015;351:h5597.

10. Baelz P. The right to strike by the caring professions. J Med Ethics. 1977;3:150.

11. Toynbee M, Al-Diwani AAJ, Clacey J, Broome MR. Should junior doctors strike? J Med Ethics. 2016;42(3):167-70. https:// doi.org/10.1136/medethics-2015-103310.

12. Park JJ, Murray SA. Should doctors strike? J Med Ethics. 2014;40(5):341-2. https://doi. org/10.1136/medethics-2013-101397.

13. Glick SM. Physicians' strikes - a rejoinder. J Med Ethics. 1985;11:196-7. 